\title{
Pós-Verdade e a Crise do Sistema de Peritos: uma explicação cibernética
}

\author{
Letícia Cesarino $^{1}$
}

Resumo

\author{
${ }^{1}$ Universidade Federal de Santa Catarina, Florianópolis, SC, Brasil
}

O artigo propõe uma "explicação cibernética" (Bateson) para a pós-verdade, partindo de reflexões clássicas sobre como a verdade ou a realidade são produzidas, notadamente em Thomas Kuhn e Bruno Latour em Vida de Laboratório. Argumenta-se que o termo pós-verdade indica um ambiente de entropia informacional crescente derivado da intensificação extensiva (global) e intensiva (personalização) do duplo processo de digitalização e de neoliberalização. A perspectiva sistêmica permite reconhecer como parte de uma mesma infraestrutura emergente fenômenos que estamos tratando separadamente como neoliberalismo, política populista, desinformação, mídias sociais, punitivismo, entre outros. Com base em pesquisa sobre a digitalização da política no Brasil, reflete-se sobre como o ambiente epistêmico contemporâneo tem se reestruturado a partir da crise de confiança no sistema de peritos, enfatizando os seguintes efeitos transversais: colapso de contextos, performatividade, verdade como eficácia, sujeitos influenciáveis, mediações (i)mediatas, invisibilização de assimetrias emergentes, conteúdo gerado pelos usuários e estruturas organizacionais do tipo pirâmide.

Palavras-chave: Pós-Verdade. Neoliberalismo. Mídias Digitais. Cibernética. Populismo.

\section{Post-truth and the Crisis of Expert Systems: a cybernetic explanation}

\begin{abstract}
The article puts forth a "cybernetic explanation" (Bateson) for post-truth, drawing on classic STS views on how truth or reality is produced, notably in Thomas Kuhn and in Bruno Latour's laboratory ethnography. It argues that the term post-truth denotes an environment of growing informational entropy, stemming from the double process of extensive (global) and intensive (personalization) digitalization and neoliberalization. Such a systemic perspective regards as part of a shared emerging infrastructure phenomena that have been dealt with separately, such as neoliberalism, populist politics, disinformation, social media, punitivism, among others. Based on research on the digitalization of politics in Brazil, it reflects on how the current epistemic environment has been restructured in the aftermath of the crisis of trust in expert systems, underscoring the following transversal effects: context collapse, performativity, truth as efficacy, influenceable subjects, (i)mmediate mediations, invisibilization of emerging asymmetries, user-generated content, and pyramid-like organizational structures.
\end{abstract}

Keywords: Post-Truth. Neoliberalism. Digital Media. Cybernetics. Populism. 


\section{Introdução}

$M$ inha intervenção na Mesa "Antropologia e Modelos Científicos" na VII ReACT foi propor um diálogo entre os campos da teoria social e das teorias de sistemas, originalmente com base em discussões sobre a emergência do populismo digital no Brasil (CESARINO, 2019; CESARINO, 2020a; CESARINO, 2020b; CESARINO, 2020c). Aqui, avançarei mais um pouco nessa discussão a partir da perspectiva que Gregory Bateson (1972) chamou de explicação cibernética. Dessa vez, colocarei em primeiro plano a chamada pós-verdade, que, como sugeri (CESARINO, 2020a), demonstra convergências estruturais importantes não apenas com o populismo digital, mas com o neoliberalismo realmente existente e com os corolários contemporâneos no punitivismo, no conservadorismo moral, entre outros (COMAROFF; COMAROFF, 2000; CHUN, 2016; MIROWSKI, 2019). Nesse sentido, o que alguns têm chamado de novo regime de pós-verdade (HARSIN, 2015) indicaria um momento liminar de crise e de reorganização nas formas contemporâneas de produção de verdade.

A hipótese de trabalho é que esses fenômenos, que a "explicação positiva" (BATESON, 1972) vê como separados, compõem um mesmo campo emergente de complexidades marcado por alterações infraestruturais profundas decorrentes da convergência, cada vez mais extensiva (global) e intensiva (personalização), entre digitalização e neoliberalização (CHUN, 2016; MIROWSKI, 2019). De um ponto de vista sistêmico ou cibernético, seria possível vê-los como um mesmo fenômeno - o que ficou evidente na vitória meteórica de Bolsonaro em 2018, cuja eficácia emanou de uma confusão inédita entre as esferas da política, da economia, da comunicação, do entretenimento, da religião e do parentesco, bem como entre divisores modernos como público e privado, indivíduo e coletivo, manipulação e espontaneidade, agência humana e maquínica (CESARINO, 2019; CESARINO, 2020b).

Se a separação funcional das esferas - para usar a expressão de Max Weber - e o arranjo da Constituição Moderna - para usar a terminologia de Bruno Latour - já fizeram sentido um dia, foi quando a sociedade e, principalmente, o Estado operavam para produzir ativamente essa diferença entre contextos. Porém, parto aqui da análise de Chun (2016), Mirowski (2019) e outros de que, desde ao menos os anos 1970, a convergência crescente entre neoliberalismo e digitalização vem produzindo efeitos no sentido contrário, de complicar e mesmo de dissolver essas fronteiras, configurando o que se tem chamado, nos estudos das novas mídias, de colapso de contextos (MARWICK; BOYD, 2011). Estaríamos, nesse sentido, em meio a um momento liminar (TURNER, 1969; CESARINO, 2020c), ou de crise de paradigma (KUHN, 2006), no qual a configuração moderna, e em especial do sistema de peritos, se desestabilizou sem que um novo arranjo 
tenha logrado se reestruturar. Nesse interregno, para usar a conhecida expressão de Antonio Gramsci, proliferam "sintomas mórbidos" - ou, nos termos de Kuhn, anomalias.

Nesse cenário, a explicação negativa ou cibernética (BATESON, 1972) ganha fôlego renovado, trazendo ao primeiro plano a operação de causalidades recursivas e mútuas, coemergências entre agentes e ambientes, topologias não lineares e dinâmicas sistêmicas que atravessam os divisores modernos. A perspectiva cibernética, ao educar a atenção analítica para vermos primeiro a estrutura, seria mais promissora para perceber padrões emergentes em momentos liminares do que perspectivas causais e lineares do tipo explicação positiva, que operam justamente por meio das categorias que vêm sendo desestabilizadas.

A primeira parte deste artigo oferece uma releitura, a partir da perspectiva cibernética de Bateson, de argumentos clássicos sobre a produção da realidade no campo dos estudos da Ciência, Tecnologia e Sociedade (CTS), notadamente em Thomas Kuhn (2006) e em Latour e Woolgar (1997). Sugiro que essa torção analítica nos permite eliciar, por detrás da aparente heterogeneidade e incoerência dos fenômenos que vimos se agrupando sob a rubrica da pós-verdade, um padrão estrutural comum de aumento da entropia, ou desorganização, do ambiente informacional, com sua concomitante reorganização em novas formas epistêmicas ainda emergentes (ZOONEN, 2012; LURY; DAY, 2019). A segunda parte estende o argumento sobre a pós-verdade para outros ângulos do campo de complexidades no qual ela vem sendo coproduzida, apontando algumas das suas ressonâncias estruturais com os populismos contemporâneos, a atual arquitetura das mídias digitais e o neoliberalismo atualmente existente. Concluo sugerindo como a arquitetura digital do neoliberalismo ou a arquitetura neoliberal das mídias digitais conformam a infraestrutura subjacente a esses padrões. O neoliberalismo contemporâneo seria, nesse sentido, fundamentalmente antimoderno, o que se manifesta em sua convergência com forças de direita de viés autoritário em muitos países (BROWN, 2019; FIELITZ; MARCKS, 2019).

\section{Um Regime de Pós-Verdade Emergente?}

Quando passei do estudo empírico do populismo digital no Brasil para explorar mais a fundo o problema da pós-verdade nele implicado, me vali da mesma estratégia analítica: um retorno aos fundamentos. Enquanto no caso do populismo eu havia recuperado a perspectiva estrutural de Ernesto Laclau articulada a elementos das teorias de sistemas e da teoria antropológica clássica - notadamente Mary Douglas, Evans-Pritchard, Victor Turner e o próprio Bateson (CESARINO, 2019; CESARINO, 2020a; CESARINO, 2020b; CESARINO, 2020c) -, no caso da pós-verdade, a aposta foi voltar à questão de como os clássicos do campo CTS entenderam a produção da verdade e da realidade.

Dois livros são fundacionais no campo CTS: Estrutura das Revoluções Científicas, de Thomas Kuhn (2006), para a história e a filosofia da ciência; e Vida de Laboratório, de Bruno Latour e Steve Woolgar (1997), para a etnografia e a sociologia da ciência. Em sua descrição da estrutura do desenvolvimento científico, Kuhn se vale de inspirações transversais a campos em que os processos análogos se insinuam: da psicologia da Gestalt 
à epistemologia genética de Jean Piaget; da teoria da seleção natural de Charles Darwin à história das revoluções políticas. Em outras palavras, a forma pela qual a ciência se desenvolve - qual seja, períodos cumulativos orientados por paradigmas estabelecidos, que eventualmente chegam à exaustão e entram em crise, sendo eventualmente substituídos por outros, incomensuráveis, mas ao mesmo tempo englobando os anteriores - pode ser encontrada em escalas diversas do mundo social e mesmo natural.

No argumento de Kuhn, o conhecimento científico se baseia em um certo tipo de organização (institucional, sociológica, cognitiva) que tem por fundamento o "tipo especial" de grupo que é a comunidade científica: fechado, autônomo, cujas fronteiras são mediadas de modo rígido pelo processo de revisão por pares e por uma pedagogia encorporada (embodied), baseada na autoridade do que Tim Ingold chamaria do "praticante habilidoso" e dos manuais que fixam o paradigma. Esses e outros processos convergem para a produção da confiança que é a base do conhecimento e da prática científicos - e é justamente a perda da confiança na capacidade do paradigma de orientar de modo eficaz a ciência normal, diante da proliferação de anomalias, que provoca a crise que antecede os processos revolucionários de troca de paradigma (paradigm shifts). Nesses momentos, que manifestam propriedades dos períodos liminares descritos por Turner (1969), ocorre uma inversão: a estrutura rígida que antes era responsável pelo sucesso da ciência normal torna-se um fator de crise e de desestabilização, e é suspensa até que seja substituída por outra em um processo de transição que pode envolver desde competição entre novos aspirantes a paradigma até períodos em que os cientistas operam de forma fragmentada e individualizada, buscando acessar a realidade de forma "menos" mediada sem um paradigma comum. Aqueles familiarizados com a mecânica das irrupções populistas descrita por Laclau (2005) provavelmente notarão muitos paralelos estruturais.

O modo como a produção do fato científico é narrado em Vida de Laboratório pode ser lido como um microcosmo da estrutura descrita por Kuhn, porém dentro da própria ciência normal. Naquela etnografia, a "descoberta" da estrutura molecular de um fator de liberação é interpretada em termos termodinâmicos-informacionais, por meio da metáfora do demônio de Maxwell, como um processo de produção de ordem a partir do caos, ou de informação a partir de ruído. Segundo essa perspectiva, a ciência normal opera intervenções sucessivas e ordenadas na "natureza" (o que os autores chamam de cadeias de inscrição) que fixam um pano de fundo - a rede sociotécnica composta no, e em torno do, laboratório - contra o qual o novo fato é "expelido" e sem o qual ele não existiria como tal.

O diagrama do laboratório a seguir, trazido pelos autores, explicita a operação da ciência como um sistema neguentrópico: assim como nos paradigmas de Kuhn, a eficácia da "ciência em ação" está em sua capacidade de reduzir a entropia, ou a tendência à desordem. Esse circuito cibernético (incompleto no diagrama, pois conta com loops externos que não estão ali representados, mas aparecem na descrição etnográfica) o faz por meio de um sistema organizado de mediações materiais e discursivas - desde os rígidos processos de inscrição burocrática envolvidos nos controles experimentais até o processo de revisão por pares; da artificialização e da padronização do ambiente na "fenomenotécnica" do laboratório (conjunto de equipamentos e outros não-humanos) a uma ética da impessoalidade e economia de credibilidade dos cientistas. O resultado é 
uma redução acentuada da equiprobabilidade dos enunciados produzidos pelo laboratório, ajustando-os de forma estável a um suposto referente no mundo "natural": em outras palavras, o resultado é a "realidade" (ou a verdade).

Figura l - Laboratório como circuito neguentrópico

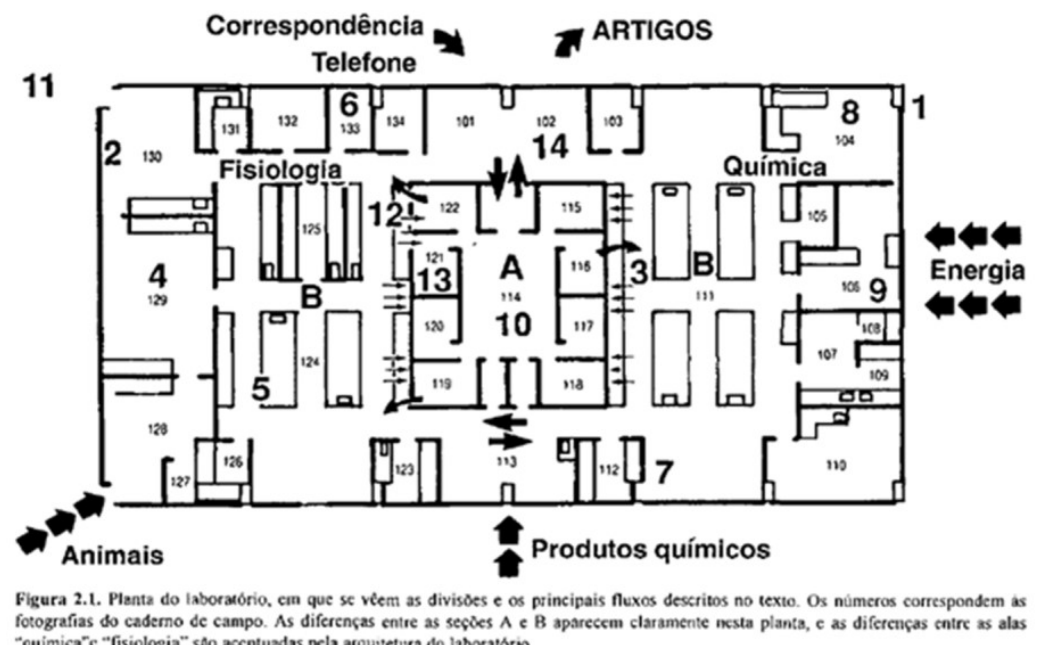

Fonte: Latour e Woolgar (1997, p. 38)

Assim como nos paradigmas de Kuhn, aqui a objetividade refere-se não a uma correspondência precisa e definitiva entre o enunciado do fato científico e um objeto dado no mundo natural. Isso seria uma impossibilidade, pois não apenas qualquer acesso ao mundo é sempre mediado - pelos sentidos, cognição, linguagem, cultura, mídias e toda a materialidade envolvida - como a incompletude inerente a esse processo sempre produz "sobras" e, portanto, contradições. O que a objetividade na ciência descreve é uma relação estável e eficaz entre enunciados e inscritores - ou mediações - de diversas ordens. Trata-se de uma relação de "controle" no sentido etimológico do termo: em suas origens medievais, o termo designava um "segundo rolo" contra o qual se verificava a autenticidade de um registro escrito ou numérico. O que a ciência faz é estabilizar este "segundo registro" contra o qual enunciados sobre o mundo (natural ou social) podem ser verificados (o termo em francês é témoin, ou testemunha). Em outras palavras, a grande meta-função da ciência em sociedades complexas como as nossas é produzir ordem, por meio da confiança social em um sistema de peritos.

Destaco esse ponto aqui, pois a pós-verdade é uma crise de confiança (ZOONEN, 2012 ) que advém de uma mudança profunda nos tipos de mediação que organizam - e reorganizam em novas bases - a produção de conhecimento legítimo nas sociedades contemporâneas. Se, nos termos de Latour e Woolgar (1997, p. 278), o que entendemos no ocidente por realidade (ou verdade) é "[...] o conjunto dos enunciados considerados caros demais para serem modificados [...]", o que se tem chamado de pós-verdade é uma condição epistêmica na qual qualquer enunciado pode ser potencialmente modificado por qualquer um, a um custo muito baixo - ou seja, em que não há mais controle, no sentido exposto há pouco. Diferentes realidades parecem proliferar em um contexto de desorganização epistêmica profunda, no qual a comunidade científica e o sistema 
de peritos de modo mais amplo deixam de gozar da confiança social e da credibilidade que antes detinham, tendo, portanto, sua capacidade neguentrópica significativamente reduzida. Nesse processo, como veremos a seguir, circuitos neguentrópicos diferentes do sistema de peritos ganham força, como a política populista, o pensamento conspiratório e "encantado", e outras formas de performatividade das mediações algorítmicas.

Embora Latour (1994) e outros autores tenham associado essa crise de objetividade a dinâmicas internas à própria ciência que teriam conduzido a uma proliferação descontrolada dos híbridos (o que Ulrich Beck chamou nos anos de 1990 da sociedade do risco), hoje está claro que essa crise de representação também diz respeito a fatores extracientíficos, em especial o avanço da neoliberalização. Notadamente, a abertura da ciência ao mercado e à financeirização tem levado ao esgarçamento dos seus consensos por influência de diferentes grupos de interesse, como aqueles por trás do negacionismo climático (ORESKES; CONWAY, 2010). O próprio Latour (2018) tem reajustado seu modo de ver as relações entre ciência e política transversalmente à "guerra dos mundos", que caracteriza a época do Antropoceno.

Minha análise parte de um diagnóstico apocalítico correlato: o que Comaroff e Camaroff (2000) chamaram de capitalismo milenarista, ou a sua "segunda vinda" na forma da virada neoliberal a partir dos anos de 1970. Desde os anos de 1990, esses autores têm mapeado, originalmente com base em materiais sobre a África subsaariana, a proliferação de práticas epistemológicas "não modernas": temporalidades milenaristas e apocalípticas (eu acrescentaria, hoje, versões seculares como o próprio Antropoceno); religiões carismáticas (também com versões seculares, como o coaching e a cultura de celebridades); rumores, linchamentos morais e físicos, vigilantismo social; teorias da conspiração e pseudociências; agências ocultas e mágicas; economias imateriais, esquemas pirâmide e outras formas de ganhar dinheiro rápido no casino capitalism; e, poderíamos hoje acrescentar, as chamadas fake news e desinformação.

Faltou aos Comaroff, contudo, pontuar o papel central da digitalização na proliferação global dessas tendências. Nesta análise, privilegiarei elementos que dizem respeito ao que poderíamos chamar de arquitetura digital do neoliberalismo, ou arquitetura neoliberal das mídias digitais. Esses fenômenos estariam ligados à difusão massiva de mediações digitais em todos os domínios da vida, desde o ecossistema de mídia e a esfera pública, passando pela infraestrutura da financeirização do capital, até o modo mais íntimo como cada indivíduo cuida da saúde, escolhe um parceiro, elege representantes e constitui sua subjetividade na era das mídias sociais, economia da atenção e plataformização (MARWICK; BOYD, 2011; HARSIN, 2015; CHUN, 2016; ZUBOFF, 2018; MIROWSKI, 2019; LURY; DAY, 2019).

Mesmo na liminaridade, é possível entrever uma ordem emergente por trás da desordem aparente. A metafísica da desordem apontada por Jean Comaroff e John Comaroff (2004) como fundamento da nossa época, constitui-se numa "dialética da produção e redução da desordem" que desafia o arranjo que Latour (1994) chamou de Constituição Moderna. A divisão de competências entre política (representação dos humanos), ciência (representação dos não-humanos) e religião (resguardada ao foro privado) foi lentamente consolidado no bojo da emergência da modernidade europeia após a ruptura provocada pela última grande revolução tecnológico-midiática (a prensa 
de Gutenberg) e pelo longo período de guerras de religião que se seguiram (FERGUSON, 2018). Hoje, temos a substituição gradual do arranjo moderno pela proliferação de mediações algorítmicas (e mercadológicas) de ciclos cibernéticos curtos, intensivos e que operam numa espacialidade de rede e temporalidade de crise permanente (CHUN, 2016) que produzem ruído constante e geram valor ao recircular, para os usuários, conteúdos produzidos por eles próprios (MIROWSKI, 2019). Diferente do sistema de peritos, esse modelo prescinde do "controle" no sentido exposto, pois não há estrutura estável contra a qual checar os enunciados que circulam on-line. A eficácia dos enunciados - sua forma de veridição - é mercadológica (FOUCAULT, 2008; MIROWSKI, 2019): se dá a posteriori, orientada pela lógica performativa do marketing, que é a base do modelo de negócios das grandes plataformas (MARRES, 2018; LURY; DAY, 2019).

Os efeitos dessa dialética - que, ao mesmo tempo em que produz desordem, reinscreve uma nova ordem que é ainda emergente - são transversais e podem ser observados em inúmeras esferas, desde o vigilantismo social e punitivismo legal (COMAROFF; COMAROFF, 2004; WACQUANT, 2009) até a ascensão mais recente dos populismos da direita radical (NAGLE, 2017; BROWN, 2019), passando pela economia da atenção e seus efeitos cognitivos (CHUN, 2016; NETO, 2020) até a precarização do trabalho e a ascensão dos conservadorismos centrados nas famílias e nas igrejas (COOPER, 2017), chegando às inúmeras formas identitárias e práticas epistêmicas que vimos agregando sob o rótulo de pós-verdade (HARSIN, 2015; ALMEIDA, 2018; FALTAY, 2020), operações de influência em guerras híbridas (LEIRNER, 2020) e, de modo mais geral, o avanço neoliberal por meio da crise permanente (KLEIN, 2008; CHUN, 2016).

Contra esse pano de fundo de entropia aumentada, identifiquei, entre apoiadores de Bolsonaro nas redes onde venho pesquisando, três estratégias de reorganização cognitiva que prescindem da confiança no sistema de peritos. Estes são encontrados, sob outras versões, também no restante do espectro político - um indicativo de que de fato refletem padrões infraestruturais. Essas atitudes epistemológicas emergentes buscam verificar a verdade não por meio dos controles e dos procedimentos fixados pelas estruturas neguentrópicas modernas (notadamente, a ciência, a imprensa profissional e as instituições do estado democrático de direito), mas da experiência pessoal e imediata, elos causais ocultos, e pertencimento identitário do tipo antagonístico.

\subsection{Sentidos Imediatos, Experiência Pessoal e "Eu-pistemologia"}

Como na ênfase na leitura direta da Bíblia pelos fiéis comuns na Reforma Protestante, uma reação à crise de confiança no sistema de peritos é uma tendência ao "literalismo" que também encontramos nas mídias digitais hoje. Boa parte dos usuários das redes bolsonaristas, inclusive o próprio presidente e outros em seu entorno, recorre cada vez mais à experiência e aos sentidos imediatos, e à trajetória de vida pessoal e suas moralidades quotidianas - o que Zoonen (2012) chamou de i-pistemology, ou "eu-pistemologia". Nos grupos de WhatsApp, por exemplo, nota-se um retorno do "ver para crer". Entre todas as mídias circuladas, os vídeos, especialmente quando gravados por pessoas comuns, pareciam carregar um grau de realidade maior por gerarem a ilusão de uma 
representação direta dos eventos. Essa experiência de não-mediação é também temporal: é como se os eventos chegassem "diretamente" em seus smartphones no momento em que acontecem. Além disso, vídeos são supostamente menos falsificáveis, e, portanto, equiprováveis (LATOUR; WOOLGAR, 1997), que textos, imagens ou áudios. A própria linguagem visual, que também é a base do marketing, tem se sobressaído atualmente em plataformas como Instagram, YouTube e Tik Tok. Esse ponto reforça o argumento sobre o caráter "elementar" da política no populismo digital (CESARINO, 2019) ${ }^{1} \mathrm{e}$ salienta como a arquitetura algorítmica dessas mídias é, hoje, desenhada para agir menos nos termos da reflexividade consciente e analítica dos usuários do que no plano pré-representacional da memória encorporada, hábitos e afetos - o chamado “cérebro reptiliano" (CHUN, 2016).

As eu-pistemologias emergem a partir da crise de confiança nas formas de produzir realidade a partir do método científico, avançando em seu lugar a legitimidade da experiência individual, da trajetória de vida, dos sentidos imediatos, dos afetos e das intuições. Um entendimento comum durante a campanha, por exemplo, era o de que quem "viveu" o regime militar saberia que ele não foi ruim para o cidadão de bem, ao contrário do que buscaria inculcar a "doutrinação esquerdista" ensinada nas escolas. A força dessa tendência entre os eleitores de Bolsonaro, e sua confluência com pensamentos conspiratórios, não é fortuita: desde 2018, sua campanha vinha produzindo conteúdos com o fim explícito de deslegitimar a academia, os especialistas e o jornalismo profissional (CESARINO, 2019; CESARINO, 2020b). É comum entre seus eleitores a ideia de que acadêmicos seriam uma elite (a torre de marfim) que "não sabe separar o mundo real da universidade", enquanto o presidente, este sim, teria acesso direto à verdade sobre o real por ser alguém do "povo". A inversão figura-fundo encapsulada na metáfora da red pill (referência ao filme Matrix), onipresente nos círculos on-line ligados à alt-right (NAGLE, 2017) e a outros como conspiracionistas paranoides (FALTAY, 2020), podia ser encontrada em inúmeros memes alegando que "o problema do Bolsonaro é falar a verdade numa sociedade que está acostumada a viver na mentira".

Esses efeitos foram ressaltados durante crises como os incêndios na Amazônia em meados de 2019 e a pandemia de Covid-19 um ano depois. Nesses momentos, falas ambivalentes e mesmo contraditórias do presidente, de ministros e de outros aumentavam a equiprobabilidade dos enunciados na esfera pública e induziam outros modos, não científicos de verificar o que é verdadeiro ou não (CESARINO, 2020d). No confronto com o então diretor do Instituto Nacional de Pesquisas Espaciais (INPE) Ricardo Galvão, por exemplo, uma mesma afirmação do presidente articulou os três aspectos que descrevo aqui: "Ele vai ter que explicar esses dados ... que pelo nosso sentimento [i] não condiz (sic) com a verdade. Até parece [ii] que ele está a serviço de alguma ONG [iii]". Outro tuite na mesma época, do então Ministro Sérgio Moro, reproduziu a versão cristã evangélica dessa eu-pistemologia da experiência mediata: “eu vi, eu ouço"².

\footnotetext{
Inclusive, no sentido de sua ressonância com padrões de animais não-humanos, como eu havia sugerido (CESARINO, 2019). Recentemente, foi demonstrado que primatas superiores, como chimpanzés, são capazes de escolher e de assistir a vídeos no Instagram (COLE; EMERSON, 2019). Desde sua origem no início do século XX, as tecnologias cibernéticas visam a camada cognitiva comum entre humanos e animais.

2 O post se referia ao apoio popular ao governo, e a expressão se refere à seguinte passagem bíblica: “Disse o senhor: de fato tenho visto a opressão sobre o Meu povo no Egito, tenho escutado o seu clamor" (Êxodo 3:7; grifo meu).
} 
Essas atitudes ressoam em entendimentos expressos por usuários comuns - numa discussão sobre estatísticas de desemprego no início de 2019 no Twitter, um eleitor de Bolsonaro me explicou que "o segredo é comparar os números com o que a gente vê na vida real". Um padrão similar foi observado durante a pandemia de Covid-19, em que dados, previsões e planejamento baseado em modelagens estatísticas foram substituídos por medidas erráticas, substituição de ministros, narrativas conspiratórias, responsabilização de inimigos e discursos ambíguos que mantinham a equiprobabilidade consideravelmente elevada (CESARINO, 2020d). Como resultado, a responsabilidade pela gestão dos riscos da pandemia recaía, em última instância, também sobre os indivíduos. Não surpreende, portanto, que meio milênio de desenvolvimento do método científico venha sendo descartado em favor de métodos caseiros como os do terraplanismo, acessíveis a qualquer um que queira aferir a forma da Terra por conta própria. Estes usuários, por vezes, se veem como os "verdadeiros" cientistas que, hoje, podem fazer sua "pesquisa" sobre qualquer assunto diretamente na internet, sem necessidade das mediações de especialistas (FALTAY, 2020).

Embora mais acentuada na nova direita, essa reorganização epistêmica é transversal à infraestrutura digital, se insinuando de outras formas também à esquerda do espectro político. A esquerda, inclusive a acadêmica, por muito tempo concentrou em si a função de massa crítica contestadora da autoridade da ciência e do próprio conhecimento acadêmico. Os estudos CTS chegaram a ser acusados pelo relativismo epistêmico e pela emergência da pós-verdade (MARRES, 2018). Com efeito, parte da militância contemporânea tem avançado suas próprias versões de anti-intelectualismo, por vezes reificando o lugar de fala e as experiências de vida dos indivíduos, assim como dos públicos segmentados nos quais suas subjetividades se constituem (LURY; DAY, 2019), como únicas bases legítimas para falar sobre o real (ZOONEN, 2012; HAIDER, 2019). Em 2018, a memética bolsonarista se aproveitou dessa transversalidade para avançar estratégias eficazes de mímese inversa (LEMPERT, 2014) - formas (slogans, padrões estéticos, dinâmicas) copiadas com conteúdos invertidos - e cismogênese simétrica (BATESON, 2008) que botaram a lógica identitária da esquerda para trabalhar a seu favor (NAGLE, 2017; CESARINO, 2019, 2020b).

\subsection{Elos Causais Ocultos}

Nas redes bolsonaristas e adjacentes, prolifera o recurso a elos causais ocultos, notadamente por meio de narrativas conspiratórias e alarmistas. Detalhei em outras ocasiões como a replicação desse tipo de narrativa desempenhou uma função metacomunicativa central no mecanismo do populismo digital, ao manter os seguidores conectados ao líder na economia da atenção extremamente competitiva que é a internet (CESARINO, 2020b). Embora essa ainda seja uma controvérsia em aberto, é possível que algoritmos como o do YouTube contribuam para a proliferação de conteúdos desse tipo, que maximizam o tempo de tela dos usuários (FALTAY, 2020). Novamente, narrativas alarmistas e conspiratórias não são privilégio da direita - vide, notadamente, os rumores e os vídeos em torno da facada em Bolsonaro. Não obstante, elas têm demonstrado maior afinidade e eficácia com a "política da transgressão" das direitas alternativas globais (NAGLE, 2017), e no 
Brasil não é diferente. É possível que a própria arquitetura da internet contemporânea introduza um viés que favorece epistemologias e comportamentos "iliberais" (FIELITZ; MARCKS, 2019).

Mais recentemente, pesquisadores brasileiros vêm se debruçando sobre a produtividade política e a estrutura epistêmica de gramáticas conspiratórias e pseudociências emergentes (ALMEIDA, 2019; FALTAY, 2020), que lembram alguns padrões epistêmicos descritos pela antropologia clássica. Como a bruxaria, o que as narrativas conspiratórias parecem fazer é "completar" as cadeias causais com o que Evans-Pritchard (2005) chamou da causa socialmente necessária, ou o que os Azande chamavam da "segunda lança". Como tem mostrado o campo CTS, atribuição de causalidade também implica atribuição de responsabilidade (accountability). Desse modo, cada usuário constrói sua versão de uma narrativa (ZOONEN, 2012) que conecta evidências esparsas por meio de uma lógica aditiva, justificando sua incompletude exatamente pelo caráter conspiratório de inimigos que supostamente a conduzem de forma oculta. Esses elos ocultos podem ser preenchidos por qualquer significante, seguindo a mesma lógica da cadeia de equivalência de Laclau (2005): George Soros, China, ONGs, globalismo, Foro de São Paulo, Jorge Paulo Lemann. Essas causalidades escondidas podem ser reveladas por meio da "pesquisa" online - um procedimento que oferece um senso de agência e mesmo de empoderamento aos usuários (ZOONEN, 2012). A lógica conspiratória converge, assim, com a das causalidades encantadas que proliferam na época neoliberal (COMAROFF; COMAROFF, 2000; CESARINO, 2020e): na versão bíblica (Marcos 4:22) evocada pelos bolsonaristas, "nada há de oculto que não venha a ser revelado".

Como na bruxaria zande, a contestação de eventos ou de interpretações particulares é incapaz de colocar em questão a legitimidade da gramática em si (FALTAY, 2020). Nesse contexto epistêmico, a "verdade se desvencilha da argumentação" (MIROWSKI, 2019) sobre evidências na esfera pública e passa a se ligar, fundamentalmente, à eupistemologia e ao pertencimento a públicos segmentados (LURY; DAY, 2019). Como me disse de modo bem direto um bolsonarista ao cabo de uma interminável discussão on-line sobre a verificabilidade das evidências na controvérsia que opôs a Vaza Jato ao "pavão misterioso" em meados de 2019: “Tudo, amigo, é uma questão de escolha. O lado que se quer estar".

\subsection{Antagonismo Amigo-Inimigo}

Por fim, talvez o modo mais fundamental de impor ordem à experiência on-line nessas redes tem sido o recurso à fronteira antagonística amigo-inimigo (LACLAU, 2005) - pilar central da "metapolítica de memes" (MALY, 2019) da campanha Bolsonaro (CESARINO, 2019; CESARINO, 2020b). Aqui, não é o conteúdo da mensagem, mas o lado da fronteira amigo-inimigo em que o emissário é classificado pelo recipiente que determinará se o enunciado é verdadeiro ou falso. Esse foi, precisamente, o sentido popularizado por Trump ao calar um jornalista da CNN em 2017 antes mesmo que ele fizesse uma pergunta: "você é fake news". Na polarização extrema que marcou 2018, o conteúdo das controvérsias também era eclipsado pela oposição entre os dois lados da 
fronteira. Uma palavra de ordem comum nas redes da nova direita, ela mesma tomada de empréstimo da esquerda numa das inúmeras mímeses inversas observadas (CESARINO, 2020b), expressa bem essa subsunção do conteúdo à forma característica da cismogênese (BATESON, 2008) em estágio avançado: "se a Globo [ou o PT, ou a esquerda] é contra, eu sou a favor" - não importa qual a substância do tema em questão. Outro slogan recorrente realiza uma dupla torção da mímese inversa, operando também como um mecanismo de defesa: uma tática que Olavo de Carvalho atribui a Lênin de "acusar os inimigos daquilo que você faz".

A descrição de Lury e Day $(2019$, p. 9) dos algoritmos de personalização como modo de individuação que inclui usuários " [...] em um tipo ou categoria com base em critérios que não são [predeterminados], mas abertos à especificação (indefinida) [...]", converge com o caráter performativo e segmentado das identidades políticas observadas nas redes. Além disso, a eficácia digital do troll, de terraplanistas e de outros parece se ligar, entre outras coisas, ao imperativo de inovação - ou, nos termos de Chun (2016), de crise permanente - que conforma a base neoliberal das mídias digitais hoje. Se, segundo a lógica algorítmica dessas últimas, o que gera engajamento é a novidade, a autenticidade, o entretenimento e o evento que demanda um posicionamento (HALL; GOLDSTEIN; INGRAM, 2016; CHUN, 2016), a intensificação do ritmo das interações acaba por levar à emergência de discursos que forçam as fronteiras daquilo que é considerado aceitável ou dizível em uma sociedade. Embora a esquerda esteja hoje largamente enredada na gramática antagonística da nova direita, replicando alguns de seus padrões - os linchamentos dos "traidores" na direita, por exemplo, encontram uma contrapartida nos "cancelamentos" da esquerda - e contribuindo ativamente para a ascensão do seu opositor via cismogênese simétrica (CESARINO, 2019; CESARINO, 2020b), essas tendências parecem, novamente, beneficiar de forma desproporcional a direita emergente.

\section{Transversalidades Infraestruturais: neoliberalismo e digitalização}

Na primeira etapa desta pesquisa, ao mesmo tempo em que eu analisava e descrevia o mecanismo do populismo digital, fui percebendo outros padrões recorrentes no material encontrado que não pareciam dizer respeito diretamente ao domínio da política tal qual costumamos entendê-lo. Alguns deles, que já indiquei anteriormente (CESARINO, 2019; CESARINO, 2020b; CESARINO, 2020c), dizem respeito a esferas sociais tão diversas quanto a indústria do entretenimento, o etos futebolístico, o culto às celebridades, as religiões evangélicas e uma pluralidade de elementos que associaríamos ao domínio econômico. Essa ampla constelação de sobreposições e de ressonâncias chamou atenção para a faceta neoliberal como algo não lateral, mas estruturante, do bolsonarismo em particular e da nova direita em geral (BROWN, 2019).

A centralidade do "posto Ipiranga" Paulo Guedes na campanha e, posteriormente, no governo Bolsonaro, escancarou a intimidade profunda entre a agenda ultraliberal do primeiro e o populismo conservador do segundo. Os "superministros" do governo Bolsonaro, Guedes e Sérgio Moro, representavam os dois pilares funcionalmente articulados das 
políticas neoliberais e do punitivismo legal observados globalmente (WACQUANT, 2009). Comaroff e Comaroff (2004) notaram como a desorganização causada pela precarização neoliberal tem gerado um desejo, tanto prático quanto cognitivo, de ordem e de segurança por parte da população - refletido em um aumento vertiginoso do encarceramento em massa, formas privadas de vingança e punição, e proliferação de figuras "heroicas" de policiais, soldados, justiceiros e outros agentes (legais ou ilegais) da ordem - como, no caso brasileiro, as milícias e as execuções extrajudiciais. Como já havia notado Foucault (2008), "não há liberalismo sem uma cultura do perigo" (p. 67).

Outra modulação contemporânea do neoliberalismo central ao bolsonarismo diz respeito à aliança entre conservadores e neoliberais que, nos EUA, vem ao menos desde os anos de 1970 (COOPER, 2017). Também aqui se observa uma retroalimentação fundamental, desta feita entre o que Fraser (1997) popularizou como políticas de redistribuição e políticas do reconhecimento, em que a defesa da integridade da família aparece como complementar à desestruturação dos pilares do Estado Social (BROWN, 2019). Em um contexto de aprofundamento das reformas neoliberais, a família passa a ocupar funções outrora públicas de cuidado do indivíduo que esteja desempregado, velho ou doente demais para trabalhar; ou mesmo, como se vê no caso brasileiro, funções de proteção contra o crime e de educação em domínios como sexualidade, cidadania ou ética. No governo Bolsonaro, o processo de convergência de agendas e de interesses entre neoliberais e conservadores chega ao extremo na adulação do atual presidente a figuraschave do movimento evangélico - mesmo não sendo, ele próprio, convertido. Não por acaso, a figura da família tem ocupado lugar central em diversas falas ministeriais, do campo da educação ao da sexualidade, da segurança e saúde públicas ao empreendorismo. No vácuo da neoliberalização, vão sendo gradualmente avançadas propostas caras aos evangélicos que implicam a ocupação, por igrejas, de funções outrora públicas como as comunidades terapêuticas e os conselhos tutelares. Talvez se possa levantar a hipótese de que essas e outras agências paraestatais venham substituindo as ONGs na passagem do neoliberalismo progressista para o conservador - o que ajudaria a explicar o lugar privilegiado destas últimas como inimigos no discurso antagonístico do governo Bolsonaro.

Há, ainda, um modo menos evidente, porém possivelmente mais profundo, com que identidades conservadoras e subjetividades neoliberais têm co-emergido na nova direita brasileira - que inclui o bolsonarismo, mas não se resume a ele. Desenvolvi em outro lugar um argumento de que a separação "conservador nos costumes, liberal na economia" subjacente ao enquadre analítico das "guerras culturais" é enganadora (CESARINO, 2019). A configuração emergente da nova direita seria propriamente bivalente, efeito de uma nova torção dialética a partir do "neoliberalismo progressista" (FRASER, 1997) que perdurou nos anos 1990 e 2000 (BROWN, 2019). Na construção da identidade popular pelo bolsonarismo em 2018, essa gramática bivalente neoliberal-conservadora se expressou, por exemplo, na desqualificação moral da luta por direitos e proteções pelo Estado como privilégios indevidos por parte de "vagabundos" e "parasitas". Políticas de redistribuição e de regulação do mercado (inclusive, o das mídias digitais) são rechaçadas por supostamente coibirem a livre iniciativa e a liberdade de expressão. Os mesmos padrões foram renovados no contexto da pandemia da Covid-19 em 2020 (CESARINO, 2020d). Com frequência, essa narrativa aparece como uma visão do Estado e da coisa pública 
como irreversivelmente corrompidos, sendo seu desmonte e substituição por mediações mercadológicas - estas sim, autênticas fontes de valor, verdade e liberdade - a única forma possível de purificação. A linguagem messiânica e vitalista da direita radical - também central a teorias conspiratórias como a do QAnon (CESARINO, 2020e) - atribui ao líder populista a tarefa de, com a mão forte, levar a cabo a vontade popular de purificar o Estado das agências parasíticas que têm impedido a justa distribuição da prosperidade. Em outras palavras, a batalha conservadora de Bolsonaro contra o "marxismo cultural" e o "socialismo" é, fundamentalmente, a batalha neoliberal contra regulações, direitos e políticas redistributivas protagonizados pelo Estado social.

Mas há, ainda, um terceiro plano de coprodução entre populismos conservadores e neoliberalismo, para o qual a perspectiva cibernética parece ser especialmente apta. Minha inspiração nesse ponto vem sobretudo de autores que têm avançado perspectivas pós-foucaultianas sobre neoliberalismo, como Jean e John Comaroff (2000; 2004), Philip Mirowski (2019) e Wendy Chun (2016). Não obstante suas diferenças, esses autores têm entendido o neoliberalismo como mais que um tipo de doutrina econômica, e até mesmo mais que uma ideologia ou cultura do capitalismo tardio: ele aparece como uma reestruturação das bases epistêmicas da modernidade. Mas o que significa pensar neoliberalismo no plano epistêmico, para além da contribuição pioneira e seminal de Foucault (2008)?

Nesta seção estenderei, ainda de modo incipiente, o argumento sobre pós-verdade feito há pouco para outros padrões de ressonância com o que se tem chamado de populismos conservadores, neoliberalismo e o modus operandi contemporâneo das mídias digitais. Embora alguns já tenham notado analogias entre pares separados dessa constelação (CHUN, 2016; WAISBORD, 2018; GERBAUDO, 2018; MALY, 2019), um olhar cibernético indica que elas são estreitas o suficiente para sugerir que, hoje, o que tratamos como fenômenos distintos são ângulos diferentes sobre uma mesma ordem emergente. Concluo apontando sete padrões estruturais dessa ordem que, como tais, atravessam o espectro político e, tampouco, se limitam à política.

\subsection{Colapso de Contextos}

Anos atrás, dana boyd avançou a ideia de colapso de contextos para caracterizar as formas de construção e de gestão das subjetividades individuais diante dos "públicos em rede" das mídias sociais (MARWICK; BOYD, 2011). A digitalização dissolve a separação entre contextos que o arranjo moderno da esfera pública buscava delimitar: público e privado, consumidor e produtor de conteúdo, fã e celebridade, espontaneidade e fabricação, indivíduo e coletivo (CHUN, 2016; LURY; DAY, 2019). Também dissolve a separação funcional entre as esferas ou os campos sociais: os fatores de eficácia da política, marketing, entretenimento, parentesco, mundo do trabalho, religião passam a se confundir cada vez mais (ZOONEN, 2012). Três décadas antes, Foucault (2008) já havia notado como o avanço da neoliberalização também se dá por processos de desdiferenciação: entre patrão e empregado, vida e trabalho, produtor e consumidor, na figura híbrida do empreendedor de si. 
A direita radical vicejou neste ambiente de colapso generalizado de contextos (NAGLE, 2017; CESARINO, 2020b). A retórica da transgressão e da vulgaridade de Olavo de Carvalho, por exemplo, tem o objetivo explícito de romper fronteiras estabelecidas entre a impessoalidade, a formalidade e a polidez da esfera pública e da política institucional (atribuída por ele a uma elite cultural marxista) e a espontaneidade e a informalidade do domínio privado (o lugar da verdade popular, que seria conservadora). Ao mesmo tempo, reorganiza o ambiente epistêmico em torno de uma fronteira amigo-inimigo traçada pelo líder (ou, no caso, pelo guru). No contexto de crise permanente sustentado pela arquitetura das novas mídias (CHUN, 2016), o "trabalho de adjacência" constante levado a cabo pela personalização algorítmica (LURY; DAY, 2019) coincide com o trabalho performativo de produção de fronteiras de grupo do populismo digital, levando recursivamente a identidades fractais que são a um tempo unitárias (de massa) e particulares (de nicho). Central a essa estratégia foi a infraestrutura da eu-pistemologia, visto que os eleitores completavam com seus próprios significados (particularidade) os significantes vazios (generalidade) disparados pela campanha Bolsonaro, colapsando, assim, a fronteira entre líder e seguidores, manipulação e espontaneidade (CESARINO, 2019).

\subsection{Performatividade}

Como outros já notaram (GERBAUDO, 2018; MALY, 2019), embora tenham trajetórias históricas independentes, o discurso populista e a memética digital apresentam hoje grande convergência em termos da sua linguagem essencialmente performativa, redundante e reducionista, com fortes componentes estéticos e afetivos. São linguagens que não descrevem uma realidade preexistente, mas geram efeitos sobre, e coproduzem, os sujeitos que comunicam (CHUN, 2016; MIROWSKI, 2019; CESARINO, 2020a). Essas também são características de habilidades neoliberais como autoajuda, coaching, assim como o empreendorismo de si e o ranqueamento comparativo hoje difundidos em todos os domínios da vida (inclusive nas e pelas mídias sociais). Os populismos da direita radical parecem substituir a lógica difusa do "melhoramento competitivo" (LURY; DAY, 2019), ligada ao neoliberalismo progressista, por uma performatividade essencialmente antagonística que encontra respaldo na homofilia algorítmica das plataformas (CHUN, 2016). Ambas as tendências colapsam a separação entre contextos que fundamentava o modelo da esfera pública liberal, baseado na formalização de uma arena impessoal e igualitária de debate sobre problemas públicos, separada do Estado e do mercado (WARNER, 2002). No lugar do indivíduo liberal clássico, a neoliberalização e a digitalização convergem numa dinâmica de formação de subjetividade que parece paradoxal do ponto de vista do individualismo moderno: uma "individuação em rede" que é, ao mesmo tempo, singular e plural (CHUN, 2016, p. 15); altamente relacional (divídua) e centrada no "eu" (ZOONEN, 2012; LURY; DAY, 2019). Em todos os casos, métricas algorítmicas tornam-se centrais a formas de subjetivação altamente performativas.

Ao se desvencilhar das mediações do modelo liberal-institucional, a política digitalizada se aproxima de dinâmicas cognitivas e de socialidade mais "elementares", aproximando-se inclusive de domínios contra os quais a própria noção de humano se 
construiu na modernidade como outros animais (CESARINO, 2019) e máquinas (CHUN, 2016). Hoje, a digitalização opera por meio de loops cada vez mais intensivos entre cognição humana e algorítmica, numa dialética intensiva de produção e de desestruturação de hábitos desenhada para extrair, da cognição elementar dos usuários, efeitos previstos no modelo de negócios das plataformas. Nos termos de Chun (2016, p. 4), “[...] constantemente perturbado, hábito [...] torna-se adicção [...]"; a sedimentação de hábitos passa de fundamento para a ação autônoma e criativa a uma forma de dependência, ou interpassividade (PFALLER, 2017). Mas, como também nota Chun (2016), a espacialidade de rede e a temporalidade de crise permanente que marcam a arquitetura contemporânea das mídias digitais também são características da governamentalidade neoliberal. Nesses termos, a coprodução entre neoliberalização e digitalização corrobora a sugestão de Mirowski (2019) de que esta última teria permitido concretizar o imperativo hayekiano de que os indivíduos comuns fossem guiados, e performados, por uma racionalidade de mercado que lhes é cognitivamente superior.

\subsection{A Verdade como a Posteriori}

A perspectiva epistêmica sobre o neoliberalismo, avançada pelos Comaroff (2000) e especialmente por Mirowski (2019), evidencia a articulação contemporânea entre os ângulos da constelação em tela. Mirowski (2019) argumenta que o "coletivo de pensamento neoliberal" - inaugurado pela Sociedade Mont Pèlerin na mesma época das Conferências Macy que originaram a cibernética - propôs mais que uma nova agenda econômica, e mesmo mais que uma agenda moral (BROWN, 2019): uma doutrina epistêmica, desenvolvida em contraposição ao que eles viam como o ímpeto planejador e a deriva autoritária do socialismo e da social-democracia. Mirowski (2019) chamou atenção para o pioneirismo de Hayek em ver o mercado não apenas como um mecanismo de alocação eficiente de recursos (como na economia neoclássica), mas como um mecanismo cognitivo, um processador de informação - o mais perfeito que poderia existir. De acordo com essa proposta epistemológica, a verdade não pode ser conhecida de antemão, mas apenas performativamente como um a posteriori, resultado da livre interação dos agentes.

Esse pressuposto fundamental, que se aproxima de um entendimento de verdade como eficácia também encontrado no campo CTS, parte de outro: nenhum sujeito, individual ou coletivo, é capaz de ter acesso privilegiado à verdade - nem o Estado, nem as estatísticas, nem mesmo a ciência. Visto a partir dessa perspectiva, que substitui a figura do planejador pela do empreendedor (MIROWSKI, 2019) e o progresso pelo risco, o neoliberalismo seria menos uma extensão ou aprofundamento da modernidade iluminista do que um projeto antimoderno. Essa última conclusão - uma glosa que eu faço da tese de Mirowski - aproxima o entendimento desse autor do modo como os Comaroff (2000) abordam as temporalidades messiânicas, causalidades ocultas e mágicas, e procedimentos oraculares característicos da época neoliberal.

Novamente, a performatividade da verdade é uma tendência transversal ao espectro político, cujos protagonistas, tanto à esquerda quanto à direita, têm atuado cada vez mais por meio da lógica da influência digital: empreendorismo de si, orientação pelas métricas, 
marketing de nicho, crowdsourcing, segmentação de públicos e outros padrões observados não apenas na comunicação política de Bolsonaro, mas em qualquer influenciador hoje (ZOONEN, 2012; LURY; DAY, 2019). Como todo padrão neoliberal, o jogo de influência baseia-se no risco - reputações e verdades exigem gestão e ajustes constantes, podendo ser destruídas tão rapidamente quanto foram construídas, refletindo o pano de fundo mais geral da metafísica da desordem e da entropia informacional que destaquei há pouco.

\subsection{O Sujeito Influenciável}

Algumas das ressonâncias mais evidentes entre a internet plataformizada e o neoliberalismo incluem o modo como as redes sociais têm operado como ferramentas pedagógicas que ensinam os usuários a se comportarem como empreendedores da própria subjetividade, inclusive política (CHUN, 2016; MIROWSKI, 2019). O populismo digital também envolve um grau importante de empreendedorismo digital, formal e informal, por parte dos influenciadores da nova direita e dos usuários comuns que se autointitularam "marqueteiros do Jair" (CESARINO, 2019). Seria apressado, contudo, aceitar sua autodescrição como um trabalho gratuito desvinculado de qualquer interesse econômico. Aqui, também colapsa a diferença entre política e empreendedorismo: navegar nas redes digitais bolsonaristas era transitar por múltiplas formas de monetização de clicks, desde canais do YouTube e click baits em sites de conteúdo duvidoso financiados por interest-based advertising até ofertas de master classes, livros e múltiplas formas de coaching por parte de influenciadores da nova direita.

Mais importante para a perspectiva cibernética parece ser, contudo, um pressuposto sobre os indivíduos que é comum tanto à arquitetura contemporânea das mídias sociais (CHUN, 2016; MARRES, 2018) quanto ao neoliberalismo como episteme (MIROWSKI, 2019) e ao mecanismo populista (CESARINO, 2020b): a sua influenciabilidade. A eficácia, tanto da mobilização do tipo populista quanto do modelo de negócios da big tech e do neoliberalismo conforme entendido por Mirowski (2019), supõe sujeitos que são influenciáveis, ou seja, que apresentam pouca resistência cognitiva às mediações algorítmicas, mercadológicas, discursivas - operadas por esses aparatos (CHUN, 2016; NETO, 2020). O quarto vértice da constelação em tela - aquilo que estamos chamando de pós-verdade - talvez seja tão simplesmente a materialização generalizada desse efeito (CESARINO, 2020a; CESARINO, 2020b).

Contra esse pano de fundo, é possível entrever que muitos usuários das mídias sociais possam estar operando com pressupostos de linguagem constativa em um universo de linguagem essencialmente performativa. Para colocar nos termos originais de John Austin (1962), enquanto a primeira funcionaria em ambientes neguentrópicos como o do sistema de peritos, a segunda parece melhor adaptada a contextos de alta equiprobabilidade como o de hoje. Nesse ponto, emergem possibilidades comparativas inusitadas com práticas epistêmicas não modernas como a bruxaria - que, em seu contexto tradicional, visava a um equilíbrio dinâmico entre enunciado e realidade (LATOUR; WOOLGAR, 1997), no qual a entropia informacional era gerida por um sistema baseado na "causa socialmente necessária" articulado de modo eficaz com a estrutura social tradicional e 


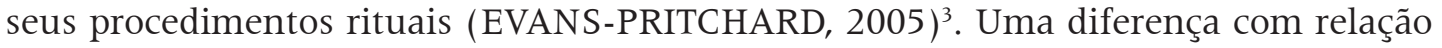
à pós-verdade é a de que as pessoas em sociedades organizadas pela lógica da bruxaria reconhecem a própria vulnerabilidade e sabem o que devem fazer para se proteger contra as agências ocultas ${ }^{4}$. Por outro lado, no atual ambiente on-line - onde tudo pode ser fake, ou não - muitos usuários não reconhecem a própria influenciabilidade e sequer reconhecem a natureza do perigo.

Esse tipo de alienação técnica vale inclusive para os nativos digitais contemporâneos, que operam apenas na interface do software e pouco ou nada sabem sobre a caixa-preta por trás da tela. Como toda forma de alienação, esta baseia-se na opacidade das novas mídias, em especial de suas dinâmicas algorítmicas. Como notou Chun (2016), o sujeito digital é contraditório: embora sempre interpelado individualmente pelos algoritmos, ele é altamente relacional, dividido e networked, totalmente dependente da rede para existir como tal e, portanto, altamente influenciável por seus loops recursivos. Não obstante, a experiência dos usuários na interface apontam para o oposto: soberania sobre o próprio perfil e a composição da sua rede, liberdade de ação e escolha, cliques como cadeia direta de comando e controle, autenticidade como padrão de legitimidade on-line, empreendorismo de si por métricas supostamente espontâneas. Como no neoliberalismo de forma mais ampla, as redes legitimam-se pela ilusão de liberdade, de espontaneidade e de meritocracia.

Esse mesmo ambiente tem, todavia, dado vazão a "sintomas mórbidos" como a ascensão de pseudociências, como o terraplanismo, e de grupos radicais e conspiratórios, como o QAnon nos EUA (CESARINO, 2020e). Ambos apresentam uma dinâmica estrutural análoga à da mecânica populista e do seu suplemento "interno", a dinâmica sectária (AYAN, 2020). Aqui também opera uma inversão, na qual quem era um outsider, um subalterno no mundo do establishment, se torna dono de uma verdade superior e exclusiva na medida em que é aceito no novo grupo. Como os ufólogos antes da internet (ALMEIDA, 2018), são grupos fechados, baseados no compartilhamento de um segredo desconhecido (ou acobertado) pela sociedade envolvente. O acesso se dá por meio de conversão, às vezes, gradual, às vezes, brusca, mas envolvendo algum tipo de Gestalt switch - frequentemente tematizado pela metáfora da red pill. Relatos anedóticos como o documentário Behind the Curve sugerem que esse tipo de fenômeno tem atraído sujeitos vulneráveis em busca do reconhecimento e de socialidade que não encontram na sociedade mais ampla - que a ultradireita on-line estudada por Nagle (2017) chama de "normies". Significativamente, terraplanismo, olavismo, movimentos antivacina e todo o ecossistema da nova direita têm se proliferado e adquirido influência por meios digitais. As diferentes veias conspiratórias se contagiam e se reforçam mutuamente - o que vai ao encontro da ênfase no conteúdo

\footnotetext{
É possível ler a bruxaria, tal qual descrita por Evans-Pritchard (2005, p. 81), como forma tradicional de gerir a entropia em um contexto de alta equiprobabilidade, em que "nunca pode haver certeza sobre se alguém é inocente de bruxaria". Ao mobilizar a bruxaria como causa, "[...] o que eles [os azande] estão fazendo é abreviando a cadeia de eventos e selecionando a causa socialmente relevante numa situação social particular, deixando o restante de lado ... pois é a única que permite intervenção" (EVANS-PRITCHARD, 2005, p. 55). Esse mecanismo neguentrópico era complementado, ainda, por "canais tradicionais, apoiados na autoridade política [dos príncipes], de controle do ressentimento" (EVANS-PRITCHARD, 2005, p. 63).

4 Agradeço a Suzane Alencar Vieira pelo insight em mesa redonda no V Encontro de Antropologia da Política em São Luís, no ano de 2019.
} 
gerado pelos usuários e nas estruturas de incentivo algorítmicas da indústria digital (MARRES, 2018; LURY; DAY, 2019).

\subsection{Mediações (i)mediatas}

O enfraquecimento de intermediários autorizados e "monopólios" de mediação que, até então, estruturavam a produção e a circulação de informação na esfera pública é constitutivo do neoliberalismo: à desestruturação do Estado social tem correspondido a fragilização de estruturas epistêmicas como o sistema de peritos e a mídia tradicional. É novamente Mirowski (2019) que faz o argumento mais contundente sobre o neoliberalismo nesses termos. Diferente dos seus precursores, o liberalismo e a economia neoclássica, o neoliberalismo envolveu a aplicação da teoria da informação à ciência econômica, ancorada no pressuposto do mercado como o processador de informação mais perfeito que poderia existir - e na premissa complementar dos indivíduos como pouco confiáveis cognitivamente. O capitalismo de dados algoritmizado parece concretizar o tipo de mediação preconizada pelos neoliberais de Mont Pèlerin - como colocou Mirowski (2019), eles não planejaram e nem criaram a internet, mas ela foi o seu "maior presente".

Uma convergência notável nesse sentido é o modo como populismo, livre-mercado, mídias digitais e pós-verdade baseiam-se todos em mediações que produzem efeitos de não mediação (MAZZARELLA, 2019). A produção de uma contiguidade entre líder e povo é, hoje, potencializada de modo inédito pelas affordances (GIBSON, 1979) do digital (CESARINO, 2019; CESARINO, 2020c). Nas redes bolsonaristas, a experiência de não mediação torna-se especialmente evidente na expectativa de que mensagens dos usuários comuns possam chegar até o smartphone das lideranças. Como também fazem os influenciadores digitais, cujas "táticas de autenticidade" envolvem a comunicação direta, constante e recíproca com sua base de fãs (HEARN; SCHOENHOFF, 2016, p. 204), o próprio presidente contribui estrategicamente para esse efeito, por exemplo, ao justificar decisões de governo com base em solicitações de seus eleitores em redes sociais. Do ponto de vista do cidadão comum, todo o aparato institucional-burocrático do sistema político-representativo passa a parecer desnecessário, supérfluo e mesmo prejudicial ao pleno exercício da soberania popular - é como se, por meio de um click, o "povo" pudesse fazer valer diretamente sua vontade exercendo comando sobre o presidente.

A ideologia do livre-mercado também se apoia no mito de que basta remover mediações - no caso, entraves regulatórios, subsídios estatais e "privilégios" indevidos para que as relações fluam espontaneamente na melhor direção possível. Mas, na prática, a agenda neoliberal funciona substituindo as políticas preexistentes por outras, que reforçam ativamente distorções, concentrações e assimetrias (KLEIN, 2008). Talvez o setor em que esses efeitos sejam mais evidentes é um dos menos regulados hoje: justamente, a indústria de tecnologia. O modo como o modelo de negócios das grandes plataformas tem estruturado a dinâmica das relações on-line é, contudo, largamente invisibilizado (NETO, 2020): do funcionamento dos algoritmos à coleta e venda de dados pessoais; das múltiplas formas de monetização a todo o aparato que Zuboff (2018) sintetizou sob o rótulo de capitalismo de vigilância. 
Finalmente, como detalhado na seção anterior, a reestruturação epistêmica provocada pela revolução digital também se baseia em mediações que se ocultam como tais: desde a percepção baseada nos sentidos individuais (o "ver para crer"), passando pelos elos causais ocultos das narrativas conspiratórias, chegando na autenticidade intrínseca que é atribuída à palavra do líder pelos seus seguidores - à medida que a base do grupo vai sendo depurada (AYAN, 2020), como ocorreu com Bolsonaro ao longo do seu governo, os seguidores que restam passam a confiar no líder cada vez mais cegamente.

\subsection{Invisibilização de Assimetrias Estruturais}

A proliferação de mediações que escondem a si próprias resulta no obscurecimento de assimetrias e de hierarquias, bem como no deslocamento da accountability. Um traço marcante dos populismos neoliberais-conservadores neste sentido, por exemplo, tem sido o deslocamento da disputa política para o plano das "guerras culturais" (NAGLE, 2017) - embora sejam eles mesmos, como sugeri para o caso do bolsonarismo (CESARINO, 2019b), bivalentes. Tanto a retórica populista quanto a neoliberal deslocam a accountability para outro lugar que não o próprio mercado, mobilizando no seu lugar significantes vazios do inimigo como o Estado (de Bem-Estar), imigrantes, bandidos, corruptos, etc. As plataformas têm seguido a mesma linha de autodesresponsabilização (ZUBOFF, 2018): preferem, por exemplo, se resguardar sob o rótulo de empresas de tecnologia a reconhecer que atuam, de fato, como empresas de comunicação - com todas as implicações regulatórias que isso poderia gerar. Toda a atual economia de reputações e de atenção operada pelas métricas de influência digital também se baseia em caixas-pretas algorítmicas e proprietárias sem accountability pública (HEARN; SCHOENHOFF, 2016).

\subsection{Conteúdo Gerado pelo Usuário e Pirâmide}

Toda a constelação que vimos abordando se baseia na extração de valor (financeiro, político, epistêmico, afetivo, identitário) a partir do comportamento e conteúdos gerados pelos usuários (NETO, 2020). No caso do populismo, sugeri que a eficácia eleitoral de Bolsonaro veio da fractalização do "corpo digital do rei": os próprios eleitores passaram a produzir e a circular conteúdos estruturados segundo a mecânica discursiva da campanha, visto que o formato digital permitiu a qualquer um replicar - de modo não necessariamente consciente - uma gramática política muito elementar (CESARINO, 2019; CESARINO, 2020b). Nisso ele não diferiu de outras celebridades digitais, que "[...] raramente precisam promover seu próprio produto, porque os fãs farão por elas" (HEARN; SCHOENHOFF, 2016, p. 205). Como no caso das conspirações, branding e de outras operações de influência on-line, a "eu-pistemologia" foi a base da eficácia da campanha: significantes flutuantes eram apropriados diferencialmente pelos usuários ao longo do caleidoscópio bolsonarista que viviam a experiência de forma espontânea e proativa (CESARINO, 2019). A centralidade, no neoliberalismo contemporâneo, do empreendorismo individual e familiar e da economia de compartilhamento e serviços em suas formas legais e ilegais, formais e informais - pode ser vista sob o mesmo prisma. 
Recentemente, Mirowski (2019) sintetizou o que parece ser o cerne da retroalimentação entre neoliberalismo e a arquitetura digital contemporânea:

Eles [o coletivo de pensamento neoliberal] não poderiam tê-lo antecipado nos anos sessenta, mas a mercantilização da internet foi o apogeu da visão de Stigler de uma ecologia da atenção das massas. Basicamente, o projeto político consiste não em convencer diretamente da superioridade do mercado sobre a sociedade num sentido didático, mas sim utilizar o mercado como um amplificador para reciclar as vulgaridades, tolices, amenidades - em suma, todo o ruído - de volta para aqueles que o produziram inicialmente, em um circuito de retroalimentação cibernético, a ponto de as pessoas perderem a noção do que se passa no seu próprio mundo. (MIROWSKI, 2019, p. 24) ${ }^{5}$

Esse modelo de negócios tem se expandido cada vez mais para o mundo off-line por meio da economia de compartilhamento, em plataformas como Uber, AirBnb e Klout. Observa-se, nessa junção, a substituição progressiva de formas fordistas de trabalho e de mobilidade social por novas formas de empreendorismo de si, além da esperança de enriquecimento rápido (e baseada no risco) típica da era neoliberal (MIROWSKI, 2019; COMAROFF; COMAROFF, 2000). Afinal, o que o neoliberalismo tem oferecido às pessoas em troca da precarização do trabalho e da vida é - nas palavras de um dos muitos parlamentares meteóricos eleitos pela nova direita em 2018 - a promessa de ganhar dinheiro "sem trabalhar muito por isso" ${ }^{\prime}$. É, todavia, uma promessa impossível de entregar a todos, e aqueles que "chegam lá" dependem do fluxo contínuo de indivíduos na base da pirâmide. Com efeito, a proliferação de estruturas organizacionais do tipo pirâmide tem sido notada em um amplo escopo de domínios: da financeirização da ciência (MIROWSKI, 2009) ao tipo de organização sectária que move o bolsonarismo (AYAN, 2020) e às fraudes, novas formas de organização do trabalho e bolhas financeiras do capitalismo de cassino (COMAROFF; COMAROFF, 2000). Nesse ciclo de recursividades emergentes, o neoliberalismo vai recriando as condições para a sua própria reprodução.

\section{Considerações Conclusivas}

Desde seus primórdios, os estudos sociais da ciência e da tecnologia têm lidado com a questão da estabilização dos fatos, ou daquilo que no ocidente se conhece como verdade. Boa parte da literatura etnográfica e histórica nesse campo tem se dedicado a mostrar como esse processo envolve inúmeras mediações e intervenções no mundo natural (KUHN, 2006; LATOUR; WOOLGAR, 1997; HACKING, 2012). Mas essa mesma literatura também mostra o quanto essas mediações vinham se dando de forma organizada, estável e estruturada, como pontuei na primeira seção. O que parece acontecer hoje - em um contexto em que hegemonia neoliberal, mídias digitais e populismos conservadores

\footnotetext{
5 No original: "They could not have anticipated it back in the 1960s, but the marketization of the Internet turned out to be the culmination of Stigler's vision of an ecology of mass attention. Basically, the political project is not to directly convince anyone of the superiority of the market for society in any didactic sense; it is rather to use the market as an amplifier to recycle the vulgarity, twaddle, gibberish and overall noise back into the public that generates it in the first place, in a cybernetic feedback loop, to such an extent that they have no clue what is actually going on in their own world".

6 Post (já apagado) de Ana Caroline Capagnolo no Twitter, em 2012, desenterrado por usuários da plataforma depois que ela foi eleita deputada estadual pelo PSL de Santa Catarina em 2018.
} 
convergem em uma espécie de "tempestade perfeita" (CESARINO, 2020a) - é a abertura caótica dos processos de produção de verdade e sua pulverização por uma paisagem digital em expansão, regulada por mediações que são invisíveis para os usuários, e mesmo para seus produtores. Porém, como nos "atratores estranhos" descobertos por Edward Lorenz - um dos ícones da teoria do caos -, parece haver uma ordem emergente por trás da desordem aparente. É possível entrevê-la se olharmos a partir da escala correta: é o que busquei indicar aqui, por meio da perspectiva cibernética.

Utilizando a distinção heideggeriana que inspirou Laclau $(2005)^{7}$, pode-se dizer que a ontologia da produção da verdade - como a descreve, por exemplo, as teorias cibernéticas e de sistemas - não mudou. O que mudou foi seu desdobramento ôntico em uma prática histórica radicalmente alterada com o fim da Guerra Fria, a ascensão da hegemonia neoliberal e suas transformações pós-2008 (BROWN, 2019) e a explosão das mediações digitais por um mundo cada vez mais desigual. O potencial de ruptura da transição que vivemos existe, embora, até o momento, boa parte das tensões propiciadas por essa infraestrutura técnica emergente pareça estar sendo absorvida nela mesma. A revolução digital em sua faceta contemporânea faz convergir diferentes aspectos da radicalidade de outras transições históricas de base tecnológica: a fragmentação antagonística radical que se seguiu à invenção da prensa de Gutenberg no século XV, que lançou a Europa em mais de um século de guerras de religião (FERGUSON, 2018); a automatização e ganho em escala permitidos pela máquina a vapor, mecanismo cibernético que consolidou o capitalismo industrial a partir do século XVIII e cujos desdobramentos hoje lançam nossas sociedades em um possível "apocalipse climático"; e a capilaridade e intensividade sem precedentes da retroalimentação humano-máquina propiciadas pelo advento dos smartphones e da economia de dados digitais, que só tendem a aumentar com inovações emergentes como a Internet das Coisas, smart cities e machine learning. Fica em aberto se essas transformações levarão eventualmente a uma ruptura, como no século XVI, ou ao rearranjo incremental rumo a um novo sistema de peritos.

\section{Referências}

ALMEIDA, Rafael. Notas para uma reflexão sobre as "teorias da conspiração". Ponto Urbe, [s.l.], n. 23, 2018.

AUSTIN, John. How to do things with words. Oxford: Clarendon Press, 1962.

AYAN, Luciano. A arte da seita política. [2020]. Disponível em: https:/ceticismopolitico. com/ensaios/. Acesso em: 28 abr. 2020.

BATESON, Gregory. Naven: um exame dos problemas sugeridos por um retrato compósito da cultura de uma tribo da Nova Guiné, desenhado a partir de três perspectivas. São Paulo: EDUSP, 2008 [1936].

BATESON, Gregory. Steps to an ecology of mind. Chicago: University of Chicago Press, 1972.

\footnotetext{
7 No caso de Laclau e Mouffe, o "político" refere-se à dimensão ontológica (ou seja, algo intrínseco à condição humana e, poder-se-ia supor, de alguma forma presente em outras culturas), e a "política", ao seu desdobramento no plano ôntico de práxis históricas particulares. Essa diferenciação ecoa formulações clássicas na antropologia sobre estrutura e prática, sistema e história.
} 
BROWN, Wendy. In the ruins of neoliberalism: the rise of antidemocratic politics in the West. Nova Iorque: Columbia University Press, 2019.

CESARINO, Letícia. Identidade e representação no bolsonarismo: corpo digital do rei, bivalência conservadorismo-neoliberalismo e pessoa fractal. Revista de Antropologia, São Paulo, v. 63, n. 1, 2019.

CESARINO, Letícia. What the Brazilian 2018 elections tell us about post-truth in the neoliberal-digital era. Cultural Anthropology, Hot Spots, 2020a.

CESARINO, Letícia. Como vencer uma eleição sem sair de casa: a ascensão do populismo digital no Brasil. Internet \& Sociedade, [s.l.], v. 1, n. 1, 2020 b.

CESARINO, Letícia. How social media affords populist politics: remarks on liminality based on the Brazilian case. Trabalhos em Linguística Aplicada, [s.l.], v. 59, n. 1, 2020c.

CESARINO, Letícia. Coronavírus como força de mercado e o fim da sociedade.

Antropológicas Epidêmicas, [s.l.], v. 2, 2020d. Disponível em: https://www.antropologicasepidemicas.com.br/post/coronavírus-como-força-de-mercado-e-o-fim-da-sociedade. Acesso em: 13 jul. 2020.

CESARINO, Letícia. O fetichismo do QAnon. Jacobin Brasil, [s.l.], 2020e. Disponível em: https://jacobin.com.br/2020/1 l/o-fetichismo-do-qanon. Acesso em: 21 dez. 2020.

CHUN, Wendy. Updating to remain the same: habitual new media. Cambridge, MA: MIT Press, 2016.

COLE, Samantha; EMERSON, Sarah. That viral video of a chimp scrolling Instagram is bad, actually. Motherboard (Vice). [2019]. Disponível em: https://www.vice.com/en_us/ article/8xzn7z/viral-video-of-a-chimp-scrolling-instagram-is-bad. Acesso em: 13 jul. 2020.

COMAROFF, Jean; COMAROFF, John. Millenial capitalism: first thoughts on a second coming. Public Culture, [s.l.], v. 12, n. 2, p. 291-343, 2000.

COMAROFF, Jean; COMAROFF, John. Criminal obsessions, after Foucault: postcoloniality, policing, and the metaphysics of disorder. Critical Inquiry, [s.l.], v. 30, n. 4, p. 800-824, 2004.

COOPER, Melinda. Family values: between neoliberalism and the new social conservantism. Cambridge, MA: MIT Press, 2017.

EVANS-PRITCHARD, E. E. Bruxaria, oráculos e magia entre os Azande. Rio de Janeiro: Zahar, 2005 [1937].

FALTAY, Paulo. Máquinas paranoides e sujeitos influenciáveis: conspiração, conhecimento e subjetividade em redes algorítmicas. 2020. 212 p. Tese (Doutorado) Programa de Pós-Graduação em Comunicação e Cultura, Universidade Federal do Rio de Janeiro, Rio de Janeiro, 2020.

FERGUSON, Niall. A praça e a torre: redes, hierarquias e a luta pelo poder global. São Paulo: Planeta do Brasil, 2018.

FIELITZ, Maik; MARKCS, Holger. Digital fascism: challenges for the open society in times of social media. Working Paper - Center for Right-Wing Studies, University of California, Berkeley, 2019.

FOUCAULT, Michel. The birth of biopolitics: lectures at the Collège de France, 1978-1979. New York: Palgrave Macmillan, 2008.

FRASER, Nancy. From redistribution to recognition? Dilemmas of justice in a "postsocialist" age. New Left Review, [s.l.], v. 1, n. 212, p. 68-93, 1997.

GERBAUDO, Paolo. Social media and populism: an elective affinity? Media, Culture $\boldsymbol{\sigma}$ Society, [s.l.], v. 8, n. 5, p. 745-53, 2018. 
GIBSON, James. The theory of affordances, In: The ecological approach to visual perception. Boston: Houghton Mifflin, 1979.

HACKING, Ian. Representar e intervir: tópicos introdutórios de filosofia da ciência natural. Rio de Janeiro: EdUERJ, 2012.

HAIDER, Asad. Armadilha da identidade: raça e classe nos dias de hoje. São Paulo: Veneta, 2019.

HALL, Kira; GOLDSTEIN, Donna; INGRAM, Matthew. The hands of Donald Trump: entertainment, gesture, spectacle. Hau - Journal of Ethnographic Theory, [s.l.], v. 6, n. 2, 2016.

HARSIN, Jayson. Regimes of posttruth, postpolitics, and attention economies.

Communication, Culture \& Critique, [s.l.], v. 8, n. 2, p. 1-7, 2015.

HEARN, Alison; SCHOENHOFF, Stephanie. From celebrity to influencer: tracing the diffusion of celebrity value across the data stream. In: MARSHALL, D.; REDMOND, S. (ed.).

A companion to celebrity. [s.l.]: John Wiley \& Sons, 2016. p. 194-208.

KLEIN, Naomi. A doutrina do choque: a ascensão do capitalismo do desastre. Rio de Janeiro: Nova Fronteira, 2008.

KUHN, Thomas. A estrutura das revoluções científicas. São Paulo: Perspectiva, 2006.

LACLAU, Ernesto. On populist reason. Londres: Verso, 2005.

LATOUR, Bruno. Down to earth: politics in the new climatic regime. Cambridge, UK: Polity Press, 2018.

LATOUR, Bruno. Jamais fomos modernos: ensaio de antropologia simétrica. Rio de Janeiro: Editora 34, 1994.

LATOUR, Bruno; WOOLGAR, Steve. Vida de laboratório: a produção dos fatos científicos. Rio de Janeiro: Relume-Dumará, 1997 [1979].

LEIRNER, Piero. O Brasil no espectro de uma guerra híbrida: militares, operações psicológicas e política em uma perspectiva etnográfica. São Paulo: Alameda, 2020.

LEMPERT, Michael. Imitation. Annual Review of Anthropology, [s.l.], n. 43, p. 379-95, 2014.

LURY, Celia; DAY, Sophie. Algorithmic personalization as a mode of individuation. Theory, Culture \& Society, [s.l.], v. 36, n. 2, p. 17-37, 2019.

MALY, Ico. New right metapolitics and the algorithmic activism of Schild \& Vrienden. Social Media and Society, [s.l.], v. 5, n. 2, 2019.

MARRES, Nootje. Why we can't have our facts back. Engaging Science, Technology and Society, [s.l.], v. 4, p. 423-443, 2018.

MARWICK, Alice; BOYD, dana. I tweet honestly, I tweet passionately: Twitter users, context collapse, and the imagined audience. New Media \& Society, [s.l.], v. 13, n. 1, 2011.

MAZZARELLA, William. The anthropology of populism: beyond the liberal settlement?

Annual Review of Anthropology, [s.l.], n. 48, p. 45-60, 2019.

MIROWSKI, Philip. The commercialization of science is a passel of Ponzi schemes. Social Epistemology, [s.l.], v. 26, n. 3-4, p. 285-310, 2012.

MIROWSKI, Philip. Hell is truth seen too late. Boundary 2, [s.l.], v. 46, n. 1, p. 1-53, 2019.

NAGLE, Angela. Kill all normies: online culture wars from 4chan and Tumblr to Trump and the alt-right. Londres: Zero Books, 2017. 
NETO, Moysés. Nuvem : plataforma : extração. Revista PerCursos, [s. l.], v. 21, n. 45, p. 5-23, 2020.

ORESKES, Naomi; CONWAY, Erik. Merchants of doubt: how a handful of scientists obscured the truth on issues from tobacco smoke to global warming. Nova Iorque: Bloomsbury Press, 2010.

PFALLER, Robert. Interpassivity: the aesthetics of delegated enjoyment. Edinburgh: Edinburgh University Press, 2017.

TURNER, Victor. Liminality and communitas. In: The ritual process: structure and antistructure. Chicago: Aldine Publishing, 1969. p. 94-130.

WACQUANT, Loic. Punishing the poor: the neoliberal government of social insecurity. Durham: Duke University Press, 2009.

WAISBORD, Silvio. The elective affinity between post-truth communication and populist politics. Communication Research and Practice, [s.l.], v. 4, n. 1, p. 17-34, 2018.

WARNER, Michael. Publics and counterpublics. Quarterly Journal of Speech, [s.l.], v. 88, n. 4, p. 413-425, 2002.

ZOONEN, Liesbet van. I-pistemology: changing truth claims in popular and political culture. European Journal of Communication, [s.l.], v. 27, n. 1, p. 56-67, 2012.

ZUBOFF, Shoshana. The age of surveillance capitalism: the fight for the human future at the new frontier of power. Nova Iorque: Public Affairs Books, 2018.

\section{Letícia Cesarino}

Professora e pesquisadora no Departamento de Antropologia e Programa de Pós-Graduação em Antropologia Social (PPGAS) da Universidade Federal de Santa Catarina (UFSC) e membro da Rede de Antropologia da Ciência e da Tecnologia (ReACT).

Endereço profissional: Departamento de Antropologia, Universidade Federal de Santa Catarina, Campus Trindade, Florianópolis, SC. CEP: 88040-900.

E-mail: leticia.cesarino@ufsc.br

ORCID: https://orcid.org/0000-0001-7360-0320

\section{Como referenciar este artigo:}

CESARINO, Letícia. Pós-Verdade e a Crise do Sistema de Peritos: uma explicação cibernética. Ilha - Revista de Antropologia, Florianópolis, v. 23, n.1, p. 73-96, 2021. 